\title{
Widening Student Participation in Higher Education through Online Enabling Education
}

\author{
Mahsood Shah, Elizabeth Goode, Susan West and Helene Clark \\ The University of Newcastle, New South Wales, Australia \\ Email: mahsood.shah@newcastle.edu.au
}

\begin{abstract}
The demand for flexible modes of delivery in higher education, especially online learning, has grown over recent years. A number of factors are contributing to the upsurge of student participation in online learning. They include innovations in technology; increased numbers of students in part-time and full-time work seeking opportunities to study at a convenient time and location; and greater use of online modes of delivery by educational providers to take advantage of the developing market. Another new phenomenon is the growth of the Massive Open Online Course (MOOC) which enables students across the world to undertake short online courses without financial cost.

This paper presents preliminary results from research into how an online enabling program in an Australian university is widening student participation in higher education. The paper compares the participation rates of various equity groups in the online program with those in the equivalent part-time on-campus program, and across the Australian higher education sector. The paper argues that the online program is playing an important role in widening participation for students from regional, low socio-economic, mature-aged and Indigenous backgrounds, and is providing women with past or present child-rearing responsibilities an opportunity to pursue higher education actively through an alternative pathway. This opportunity has made it possible for disadvantaged students from diverse backgrounds to gain a qualification for undergraduate admission and contribute to labour market needs in areas of skills shortage.
\end{abstract}

Key terms: enabling education, online learning, widening participation

\section{Introduction}

The quest to widen student participation comes at a time when governments in some countries are introducing concurrent policies focused on ensuring that the growth in numbers of students in higher education does not compromise academic quality, standards and student outcomes (Shah et al., 2011: 266; Whiteford et al., 2013: 300). For example, in the Australian context, the government has warned that growth of student numbers in universities must not compromise academic quality and outcomes (The Age, 2011: 5; Trounson and Hare, 2011). While the government has cautioned universities about maintaining quality and standards despite increased participation by disadvantaged students, the national agency responsible for monitoring quality is yet to develop innovative quality assessment practices 
which acknowledge institutional missions to widen student participation while maintaining appropriate academic standards.

The widening of student participation in Australian universities is driven by two key imperatives: government policies which provide additional funding for universities that aim to increase the access and participation of disadvantaged students; and university missions to increase the participation of students from equity groups. Various initiatives have been implemented by universities in Australia to take advantage of funding designed to widen access to higher education. They include: (1) the establishment of University Colleges that provide a pathway into the second year of undergraduate programs via first year diploma or associate degree programs; (2) increased partnership between universities, vocational providers, and high schools; (3) lowering the entry score in some programs to enable the increased participation of disadvantaged students; and (4) alternative entry pathways for students such as enabling or tertiary preparatory programs. Enabling programs are preparatory courses which on successful completion qualify students to apply for entry into undergraduate programs. These programs cater for students such as recent school-leavers who have not obtained a sufficient entry rank for university or who have dropped out in senior years of secondary education; mature-aged adults; and students from Indigenous, low socio-economic, first in family, non-English speaking, and refugee backgrounds.

This paper is based on one Australian University that has been offering enabling programs since the 1970s. For many years students from various equity groups such as Indigenous students, women who have experienced a gap in their employment or education, individuals from non-English speaking backgrounds, refugees, people with disabilities, those from regional or remote areas, and first-in-family students, have been participating in enabling programs and accessing undergraduate education. For example, the university has a proud history of increasing the access and success of Indigenous students in its medicine, nursing and allied health programs (Behrendt et al., 2012:163). Enabling programs at the University represent $15-17 \%$ of the total commencing domestic undergraduate student enrolment. Studies have shown that students who enrol in enabling programs have often experienced a range of barriers limiting their access to higher education. These include, but are not limited to: location and distance from the University; financial pressures; low academic achievement in high school; failure to complete high school education due to illness or other personal reasons; lack of appropriate careers advice; parental discouragement of higher education due to limited university education attainment within the family; a lack of confidence in one's ability to undertake university education; parenting or carer responsibilities; mental health issues; and a variety of other social problems (Beyer, 1995 and Bowers-Brown, 2006). 
This paper provides preliminary findings on how the Open Foundation Online program at the University of Newcastle, Australia, is widening student participation both within and beyond the University's geographical footprint. Until now research on widening participation and online learning has been more focused at undergraduate and postgraduate level. Few studies have been undertaken on enabling or preparatory programs, especially those that are wholly online. The paper aims to make a first foray into answering the research question - to what extent has the online enabling program widened student participation in higher education?

The paper contrasts the participation rates of mature-aged, female, low SES, regional/remote and Indigenous students in the online program with those from the on-campus offering of Open Foundation, and with national average participation rates. The data presented in this preliminary findings shows that the online program consistently enrols higher proportions of equity groups than the equivalent on-campus offering, and the sector nationally. Female, mature-aged, regional/remote and low SES students are particularly highly represented in the online program. Coupled with data which shows that the vast majority of students who complete Open Foundation enrol in undergraduate degrees, this suggests that the online delivery of enabling programs can make a valuable contribution to widening participation in higher education. The paper begins by assaying some of the international and national literature on the relationship between flexible learning modes and widening tertiary participation.

\section{Flexible learning and widening participation: international perspectives}

Advances in technology have widened student participation in higher education (Packham et al., 2004:335). In the USA President Obama proposes to achieve a target of $40-60 \%$ of Americans graduating from college by 2020, in part by encouraging the modernisation of schools and the use of the latest technology in teaching, measuring and administering coursework (Sturgis, 2012). A review of the literature suggests that one of the reasons institutions adopt online learning is to widen student access to higher education (Garrett \& Jokivirta 2004; OECD 2005:74; Schiffman et al. 2007). Research undertaken at Glasgow Caledonian University, UK, regarding the online delivery of pre-entry programs suggests that technology use has increased the access and participation of disadvantaged students (Mckendry 2012/13:229). According to Whittington et al. (2004:1803) the introduction of a postgraduate program in reproduction and development in one UK University has widened student participation and provided the opportunity for many students to access online courses from different geographic locations. 
Students involved in online courses enjoy flexibility in terms of at least one of these elements: time, place, pace, learning, style, content, assessment and pathways. (Chen, 2003:25). Online learning is therefore attractive to a diverse range of students who might otherwise find educational participation difficult or impossible for reasons such as family commitments, work or financial constraints, disability or geographical location (Brown et al. 2012:74). A study of disadvantaged students undertaking online courses offered by the Open University UK shows that the top three reasons for choosing to study online include: availability of the subject online; wanting to increase IT competency; and flexibility (Knightley, 2007:278). Knightley's study found that the online delivery of courses had enabled disadvantaged students to access education more easily and flexibly than traditional, print-based, and distance learning courses. Another study at Open University UK found that a large percentage of ethnic minority students choose online tutorials (80\%), compared to $54 \%$ of mainstream students. The same study also found that $60 \%$ of ethnic minority students had other commitments which prevented them from attending tutorials, compared to $51 \%$ of non-ethnic students. In the UK, an Open University study found that $80 \%$ of ethnic minority students chose online tutorials, while only $54 \%$ of mainstream students made the same choice. Of the two groups, $60 \%$ of the ethnic minority students had other commitments while just 51\% of non-ethnic students did (Richardson, 2012:22).

A variety of studies have shown that learning online has 'transcended geographical, physical, visual and temporal barriers to accessing education, and reduced socio-physical discrimination' (Bossu et al., 2012:152; Debenham, 2001; Gorard \& Selwyn, 1999:523). Kemmer (2011/12:61) argues that the flexibility of online learning could potentially widen participation; however, students need to be independent learners capable of taking responsibility for their learning. A recent Australian study found that educational technology had a functional, rather than a focal role, in encouraging relationships and activities that resulted in learning and success for disadvantaged students (Dawson et al., 2013:710). Finally Matas and Allan (2004:10) conclude that for mature-aged students, the benefits of using online learning portfolios were applicable in educational settings as well as in the workplace.

Staff are often less positive than students about online learning (HeatonShrestha et al., 2009:89). Nonetheless, one study demonstrates that teachers were engaged in more ongoing communication with their online students than with their on campus ones. Indeed, some teachers got to know their online students better as online communication was less constrained by timetabling demands (Diaz \& Entonado, 2009:331). Interactive and collaborative models of learning are encouraged by the online learning environment (McDonald \& Reushle, 2000:290; Segrave, 2004:39). As Knightley points out, 'the varied approaches made possible by online learning platforms provide a rich, interactive learning environment within which students can engage more fully with course content using different 
media, and interact with others in a collaborative way that makes learning more effective' (Knightley 2007: 268).

Importantly, research suggests that students who complete online courses perform just as well academically as their face-to-face counterparts (Ashby et al., 2011; Dell et al., 2010; Navarro \& Shoemaker, 2000). Some studies have even concluded that online students tend to outperform their oncampus counterparts (Ladyshewsky, 2004; Long et al., 2011), and suggest that online learning is particularly beneficial for students with disabilities such as hearing loss (Long et al., 2011). A study of Native American students' adaptation to online learning environments suggests that a flexible mode of delivery is an effective way to deal with non-traditional students' range of academic abilities and other life issues. Kaler (2012:73) found such students are able to study independently; learn time-management skills and control the pace of their learning. A study in Sweden and Scotland monitored the academic performance of students in both face-to-face and online modes and concluded that there were no differences between the grades, or test scores, of the two groups of students (McPhee \& Söderström, 2012:152). Other research in the UK concluded that the academic performance of students in face-to-face or online tuition is comparable between mainstream and ethnic minority students (Richardson, 2012:25). A recent study in China found that as distance/online learning in the higher education sector expanded, educational equality between China's provinces also improved (Li et al., 2013).

While there is evidence that online education encourages disadvantaged students' participation in tertiary education, there remains some doubt as to 'the extent to which utilising information and communications technology (ICT), e-learning or online learning overcomes barriers to participating in higher education' (Lax, 2001; Looi \& Lim, 2006; Martin \& Williamson, 2002:52; Simpson, 2005). Online education is one means of achieving personally, academically and economically (Knightley, 2007:278). For example, Ghanaian research found that open and distance learning led to greater participation by women (Kwapong, 2008). According to Tight (2012:212), however, decades of attempts to increase the participation of low socio-economic background students have produced limited results when compared to other groups such as women, mature adults, and ethnic minorities.

Nonetheless, various studies suggest that providing online education has widened student participation in higher education. It is unclear though whether institutions have implemented online learning to widen underprivileged student participation, or have been using the innovative technology to meet the demands of all students who consider an online mode of higher education attainment to be a viable and flexible alternative to traditional face-to-face learning. 


\section{Open Foundation Online}

This paper reports on the Open Foundation Online program offered by the University of Newcastle, Australia. Open Foundation is one of three enabling programs offered by the university explicitly to provide access and opportunity for disadvantaged domestic students seeking an undergraduate education. These students include mature-aged adults from Indigenous, low socio-economic, first-in-family, English as a second language and refugee backgrounds, as well as women returning to education and students with a disability. Unlike undergraduate and postgraduate study which incurs debt for domestic students, the enabling programs at the University are free and students can withdraw at any point without financial penalty.

The Open Foundation Online program commenced in 2003 after the ongoing growth of a similar program offered in traditional face-to-face mode. Originally the program was a paper-based distance program; however it is now delivered in fully online mode through the Learning Management System (LMS) Blackboard. Since its first offering in 2003, Open Foundation Online has grown from 40 enrolments to some 400 enrolments annually. The program requires students to undertake 40 units of study through a part-time load across two semesters. Students gain one year of tertiary preparation, and upon successful completion of the program can apply for undergraduate admission at the University of Newcastle or a range of other Australian universities.

The online program was established to provide access and flexibility for students who were seeking to enrol in undergraduate education, but who could not attend classes on campus. Similarly to their face-to-face counterparts, students who enrol in Open Foundation Online do so for a variety of reasons. These may include: the need for an alternative pathway for university admission; seeking the confidence to undertake undergraduate education; self-assessing the level of academic preparedness required for higher education; and the desire to attain a qualification which may lead to further education opportunities and enhanced career prospects.

\section{Method and Findings}

The paper is based on preliminary findings from quantitative and qualitative data collected between 2008 and 2013. The quantitative data was obtained from enrolment records in the University's Student Record System for staff, NUSTAR. The authors downloaded lists of students who enrolled in Open Foundation Online or Part-time Open Foundation at the Callaghan Campus from 2008 to 2013. Using the demographic data on these lists the authors identified and compared the participation rates of various equity groups across the two modes of study. 
Five equity groups were identified for analysis: students aged over 25; women; students from low socio-economic status backgrounds; enrolments from regional or remote locations; and Indigenous students. Yearly enrolment numbers across three of these equity groups - students aged over 25, women, and Indigenous students - could be obtained directly from the NUSTAR-generated lists, while residential postcodes were used to determine the participation rates of low socio-economic status and regional/remote students. To obtain numbers of students in low, medium and high socio-economic areas, the authors analysed students' postcodes with reference to the Index of Education and Occupation (IEO), one of four Socio-Economic Indexes for Areas developed by the Australian Bureau of Statistics (Phillimore \& Koshy 2010). According to this method, students from low socio-economic backgrounds are defined as "those whose permanent home address postcode falls within the lowest 25 per cent of postcodes" as coded by the IEO (Bradley et al. 2008:34). Students' postcodes were then also analysed with reference to the Australian Standard Geographical Classification (ASGC), which categorises Australian postcodes into one of six major categories: Major Cities; Inner Regional, Outer Regional, Remote or Very Remote Australia; and Migratory areas. To allow for wider comparisons across all five equity categories studied, data relating to the participation of these demographic groups in the broader Australian higher education sector was also obtained from government publications.

In addition, qualitative data was collected from student surveys and discussion boards and blogs in the online LMS Blackboard. Student comments were de-identified and manually colour coded to identify key recurring themes. The presentation of this preliminary data begins with mature-age students (defined below), since the majority of the students in Open Foundation Online fall into this category.

\section{Mature-aged students}

Mature-aged university entrants are generally considered 'non-traditional' students in countries such as Australia and the UK (Bowl, 2001:142; Cantwell et al., 2001; Crossan et al., 2003; Tight, 2012:213). While the age at which a student may be considered mature-aged varies, it has been recognised that students aged 25 years or more tend to differ from their younger counterparts in a number of significant ways (Tones et al., 2009; Western et al., 1988). As Bowl articulates, "the 18-year-old student can build social and academic support networks around university life . . . for the non-traditional student financial responsibility, childcare, family and community expectations are central features of life, around which study must be fitted" (2001:142). In an Australian context more mature-aged students are entering university than ever before - often via enabling programs - and many of these students are choosing to study by distance and/or online in order to juggle their competing responsibilities (Bradley et al., 2008). 
Figure 1: Open Foundation Students Aged over 25, 2008-2013

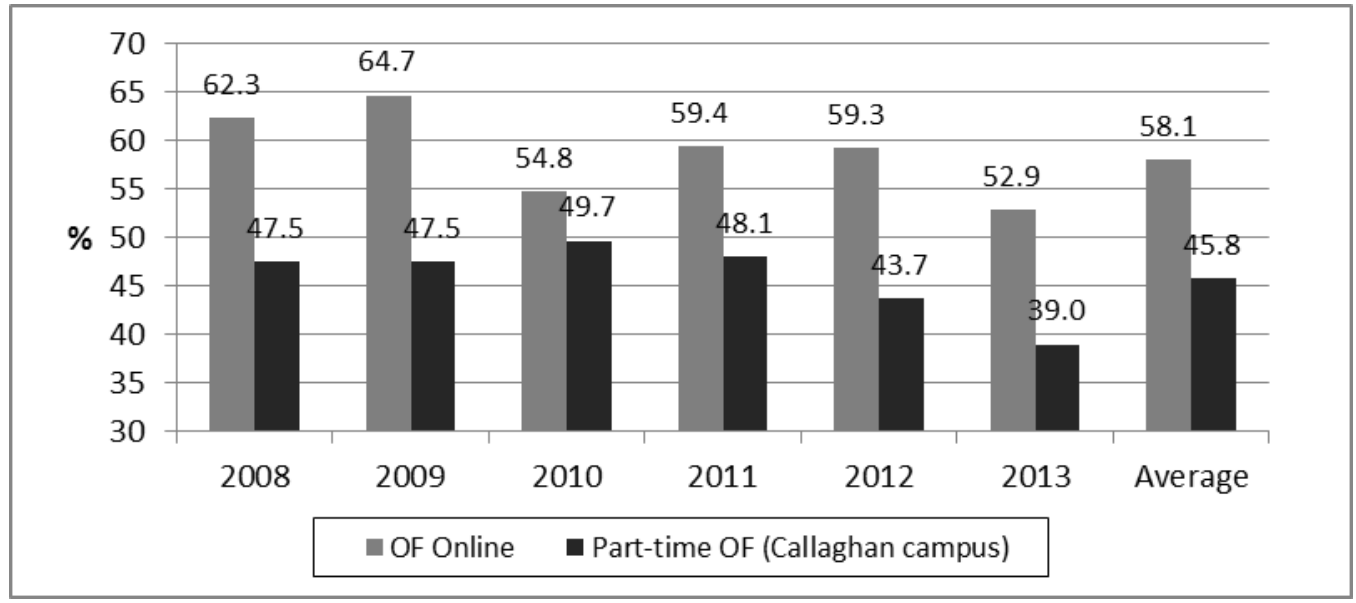

While the average age of students enrolling in Open Foundation, both oncampus and online has been growing progressively younger since the late 1980s (Kavanagh et al., 2011), a significant proportion of enrolments in the online program each year are aged over 25 . Figure 1 shows that, on average, $58.1 \%$ of students who commence Open Foundation Online are aged 25 or more. This is somewhat higher than the average in the on-campus program (45.8\%), which suggests that mature-aged students tend to perceive that online study will be a better 'fit' given their lifestyle and other commitments. When compared to enabling programs Australia-wide, the participation rate of mature-aged students in the online program is also higher than the national average of 51\% (Department of Industry, Innovation, Climate Change, Science, Research and Tertiary Education [DIICCSRTE], 2013). It is significantly higher than the average among Australian domestic students of 25\% (DIICCSRTE, 2013). And, as the data below shows, a high proportion of these students are female.

\section{Women in Open Foundation Online}

Research suggests that the reasons for women enrolling in enabling programs are varied. They range from economic incentives (Kaziboni, 2000:231) to the desire for self-improvement and 'identity regeneration' - a re-casting of personal identity to encapsulate aspects other than being a wife or a mother (Cantwell and Mulhearn, 1997). According to Tight (2012:212), from the 1990s onwards, more mature-aged women have sought to participate in higher education after periods of employment and/or raising families. Perhaps on account of these trends, women typically enrol in enabling programs at higher rates than men (Collins \& Penglase, 1991; Cullity, 2006:506; Ramsay, 2004).

Aligning with these findings, Figure 2 shows that women have consistently participated in Open Foundation Online at much higher rates than their male counterparts. For all six years analysed for this paper, the percentage of female students has exceeded $70 \%$. On average, women have 
comprised 73.2\% of each annual cohort between 2008 and 2013. Furthermore, comparative data from the on-campus Open Foundation program shows that the proportion of female enrolments is typically much lower in the face-to-face mode, ranging from $55 \%$ to just over $60 \%$.

Figure 2: Female Students in Open Foundation, 2008-2013

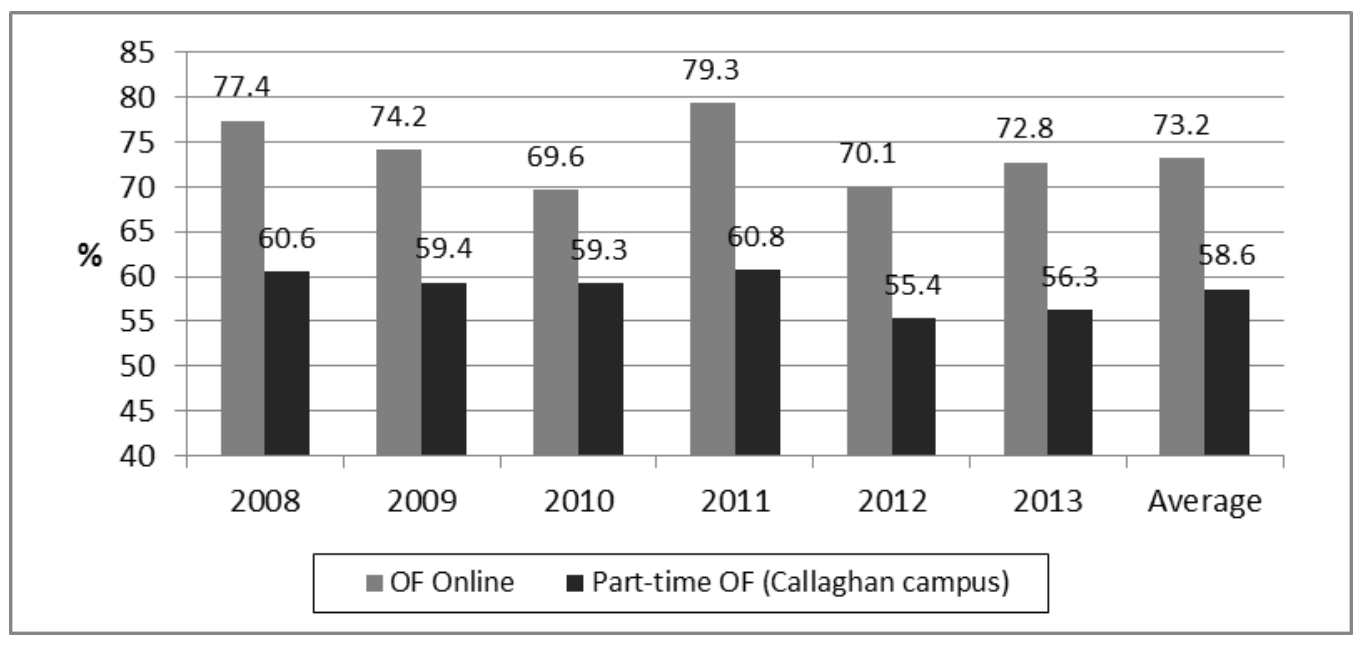

A large proportion of the female students completing enabling programs at the University of Newcastle choose to study nursing or education at undergraduate level. Internal data shows that each year almost $50 \%$ of enabling completers enrol in education, nursing and other health-related undergraduate programs. Enabling programs have therefore played an important role in addressing skills shortages in both nursing and teaching professions in various communities.

\section{Low socio-economic status students}

In 2009 the Australian Federal Government announced a national target of increasing the participation of students from low socio-economic backgrounds in higher education to 20\% by 2020 (Department of Education, Employment and Workplace Relations [DEEWR], 2009:13). The number of students from low socio-economic backgrounds enrolling in Open Foundation Online is therefore a key indicator of how online enabling programs may be widening participation in higher education.

From the late 1980s, the proportion of students from low socio-economic backgrounds enrolled in Australian universities has consistently been around 15\% (DEEWR 2009). By contrast, the percentage of students from low socio-economic backgrounds in Open Foundation Online has ranged from $26.6 \%$ to $36.8 \%$ across the six years to 2013. As shown in Figure 3, on average $31 \%$ of Open Foundation Online students are from low socioeconomic areas each year. This data indicates that the participation of low socio-economic status students in Open Foundation Online is significantly higher than the national average, and already exceeds the national target proposed by the Australian Federal Government for 2020. Again, it is also 
evident that the online program consistently attracts a higher proportion of low socio-economic students than the on-campus program. This situation is mirrored by the geographical areas from which students are drawn.

Figure 3: Open Foundation Students from Low Socio-economic Backgrounds, 2008-2013

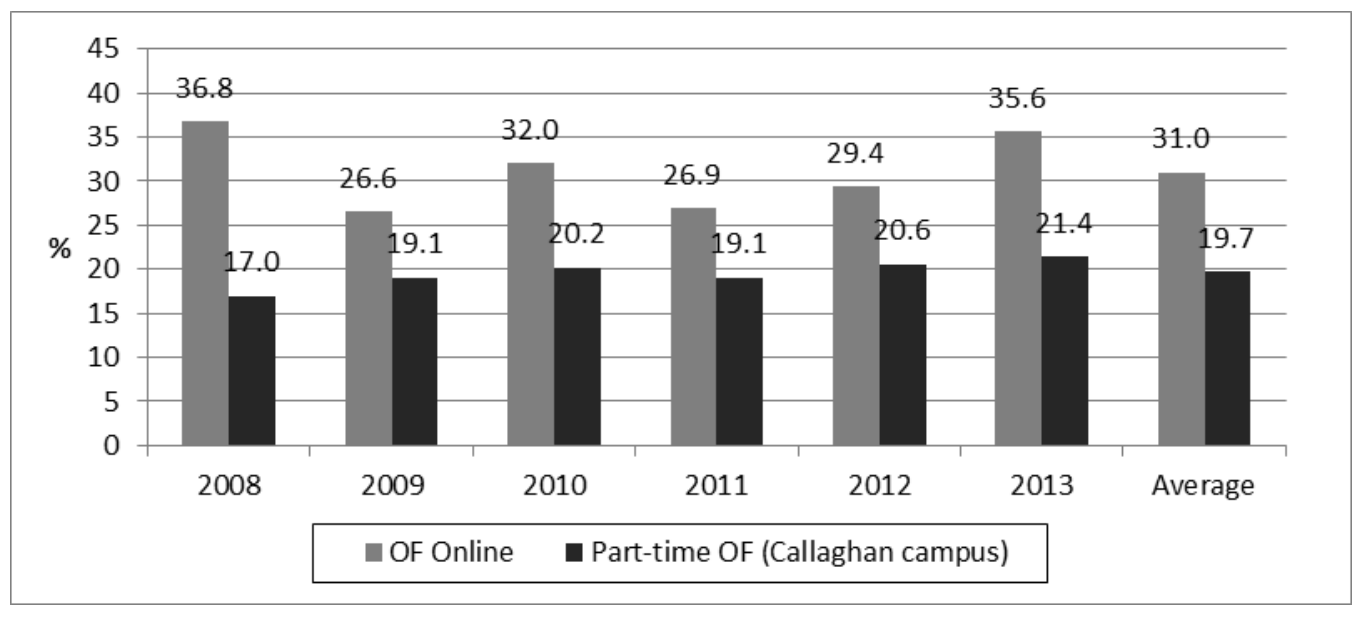

\section{Geographical distribution and regional/remote students}

Trend data shows that students from a wide range of geographical areas have sought access to higher education through Open Foundation Online. Students have been spread across all seven states and territories of Australia, from as far west as Perth in Western Australia to Sydney in New South Wales - cities which are 3,300 km apart. Online students have enrolled from some of the most remote areas of Australia, including central Australia, western New South Wales and northern areas of Western Australia.

Analysis of the home addresses of Open Foundation Online students across 2008-2013 revealed that 33.1\% of enrolling students during this time period were located in areas classified as either Regional or Remote. While the percentage of Open Foundation Online students from non-metropolitan areas declined between 2008 and 2011, this average figure is still higher than the national University sector average of 20.4\% (DIICCSRTE, 2013), and significantly higher than the average in on-campus Open Foundation. 
Figure 4: Open Foundation Students from Regional and Remote Areas, 2008-2013

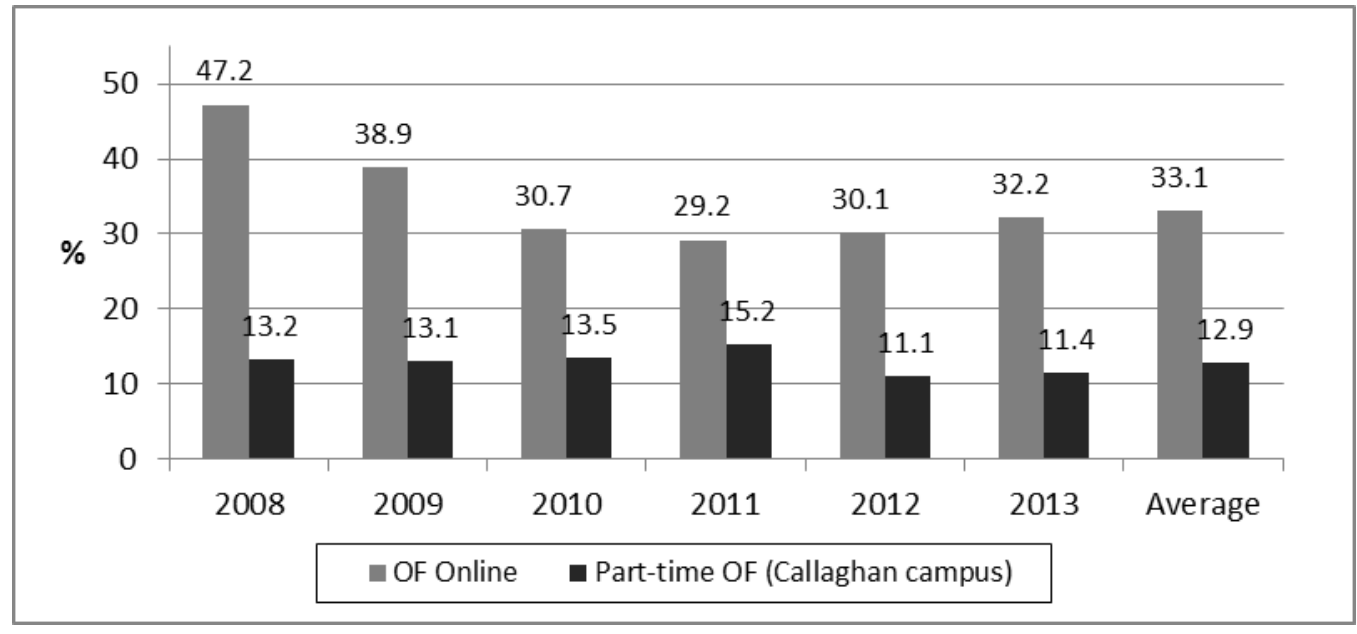

In 1991, a study of Open Foundation students found that $44 \%$ of students were travelling between one and five hours to attend classes (Collins \& Penglase, 1991). Some students were travelling in excess of $600 \mathrm{~km}$ in order to access and complete the program, which was at that time only offered oncampus (Collins \& Penglase, 1991). In 2013, 38.5\% of students enrolled in Open Foundation Online indicated that they either did not live near University of Newcastle campuses or could not easily travel to or from a campus. Being able to complete Open Foundation Online therefore provides a range of students who otherwise would not be able to participate in higher education, or who would have to travel long distances in order to do so, with an opportunity to study from regional, remote and metropolitan locations around the country. Analysis of the final set of quantitative data collected for this paperrevealed the proportion of these students who identified as Indigenous.

\section{Indigenous students}

Indigenous students are consistently recognised as an equity group that is under-represented in the Australian higher education system (Behrendt et al., 2012:10; Birrell et al., 2000; Bradley et al., 2008; Collins and Penglase, 1991; Department of Employment, Education and Training 1990:10; James et al., 2004:55; Krause et al., 2005:67). According to recent figures, only $1.0 \%$ of students in Australian universities are of Aboriginal or Torres Strait Islander descent (DIICCSRTE, 2013).

In contrast, Figure 5 demonstrates that Indigenous students have consistently comprised more than $2.5 \%$ of each annual intake in both online and on-campus Open Foundation. Indigenous students were the only equity group recognised as having similar participation rates in both modes of delivery. The proportion of Indigenous students in the online program peaked at 4.3\% in 2013, and averages 3.3\% across the six years from 2008 to 2013. While still a modest percentage, in light of the national average this 
represents a significant widening of access to higher education among Australians of Indigenous descent.

Figure 5: Indigenous Students in Open Foundation, 2008-2013

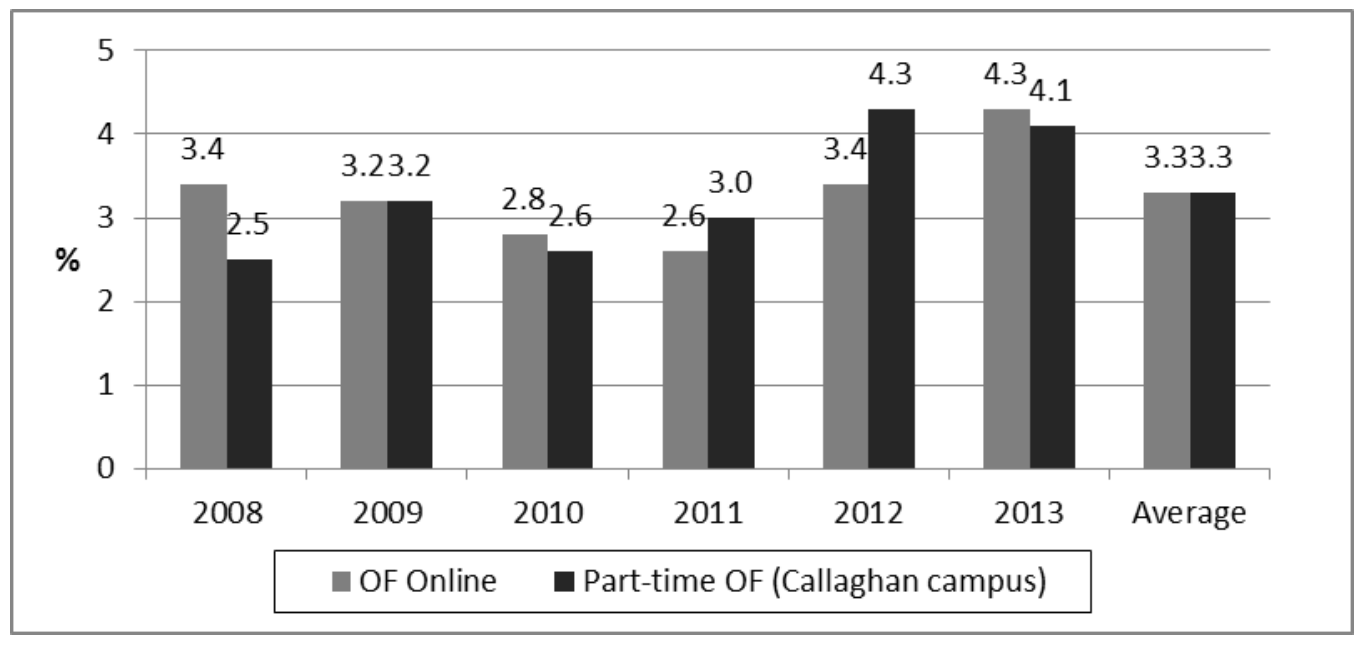

\section{Access and Opportunity for Students}

The data presented thus far demonstrates that the Open Foundation Online program has indeed provided an opportunity for many disadvantaged students to assess their readiness for university and to access a pathway to higher education. The qualitative data collected from surveys and from the online LMS Blackboard supports these findings by providing insight into how and why these students value the opportunity to study online at times and places that suit them. The three most prominent recurring themes regarding how Open Foundation Online has provided access and opportunity for disadvantaged students include: the value of being able to return to study in a flexible mode after or during child-rearing years; appreciating a chance to prove that one is capable to attain undergraduate degree; and the importance of building confidence for further study.

Student feedback has consistently demonstrated that many female students in Open Foundation Online value the opportunity to balance study with caring for family and children. The number of female students in the online program who are concurrently balancing family commitments is a testament to the notion that women are increasingly becoming more proactive in pursuing educational attainment and long-term career development. Student comments which suggest that more women are seeking ownership of higher education attainment while balancing caring responsibilities include:

'I live far away from the campus and online is an easier way for me to fit it in with running the house and keeping up with the kids.'

'I work part time and also care for my elderly parents, so I couldn't attend Uni full time. My study has to be flexible so I can study wherever and whenever I choose.' 
'I am studying online because I have a four year old daughter at home and she only attends preschool three times a week and I have no family support for child minding.'

'The reason I chose to study online was because I was working full time, looking after my 2 year old son, and had a baby girl in May. With everything going on in my life it is a lot more convenient to study at home and also that way I wouldn't miss anything or need to take any time off from studying when I had my baby.'

A number of students have also indicated that Open Foundation Online provided them with an opportunity to pursue aspirations that they had 'shelved' in order to raise young children.

'The reason behind my choice was that I have 3 children 2 at school and 1 at home, my husband works away a lot so I need to be around a lot for the kids. I am really focused on becoming a nurse, and not having completed yr 12 OF was a great opportunity for me to hopefully gain entry into University to follow the dream.'

'I would like to reach the goal of becoming a primary school teacher, a dream that I put on hold so I could dedicate time to family.'

These comments clearly suggest that without an online enabling pathway, access to higher education would have been difficult, if not impossible for many women with carer responsibilities.

Comments also indicated that Open Foundation Online provides many students with a chance to prove to self and to others that they are capable of undertaking an undergraduate degree. It is evident that many disadvantaged students have aspirations of attaining higher qualifications after completing Open Foundation Online, and that the program is providing these students with a means of self-assessing their readiness for higher education. As the comments below indicate, this opportunity was highly valued by many of the online students:

'I have been talking about doing a University course for years. I decided it was time to put my money where my mouth was and do it. I am the only one of my siblings who does not have a university degree and I know I am smarter than them both so I have something to prove ... I felt it was time to empower myself.'

'I'm very appreciative that this course is available to people like me who through no fault of their own missed out on the opportunity to complete their high school education. Prior to starting this course, I had pretty much given up, accepting that I will have to work a 'blue collar' job that I dislike for the rest of my life. I now have long term goals to attain a degree and pursue a career that I am interested in; if I achieve these goals then I am sure to have a better quality of life due to earning potential and job satisfaction.' 
'Open Foundation will finally allow me to do the degree that I wanted 20 years ago when I originally finished high school. Open Foundation will further my learning to see how I would cope with studying at undergraduate level.'

A flexible, open access program such as Open Foundation Online allows many disadvantaged students to make a second attempt at accessing higher education. Student comments suggest that they value and appreciate the opportunity to participate in a pathway program which dissolves barriers presented by time, location and personal circumstances.

The third recurring theme identified in the qualitative data relates to student confidence. Similar to many enabling students, those enrolling in Open Foundation Online tend to lack confidence in their ability to attempt undergraduate education. Often this is due to a history of poor academic achievement and/or a gap between high school attainment and further study. Student comments suggest that a fear of going to university is frequently underpinned by these factors, along with other factors such as a lack of support from family members. Following the online orientation at the beginning of Open Foundation Online - Week Zero - many students reflected on how their need for confidence was met by engaging in the online program:

'I realised there is lots of support \& help available ... Admittedly, I was feeling a little overwhelmed and not sure a mature person like myself would be too long out of school to participate in such an academic field. I am now feeling a little more "normal”.'

'As I haven't studied for over 25 years I felt I needed all the help I could get and week zero was a large part of that in gaining my confidence to enter open foundation studies.'

Throughout the semester students continued to express how the online program allowed them to build their confidence in a safe and supportive environment:

'I am quite shy and it was a way to get involved without putting too much pressure on myself by having to meet a lot of new people face to face. Now that we are half way through and I have attended the face to face days, I have found everyone I meet to be so helpful and friendly. I have gained so much confidence by completing assignments and sitting exams. Even though it has been a lot of work, it is one of the best things I have ever done.'

'Online was the favourable choice to fit in with my other commitments ... [and I was] also a little scared to attend Uni all by myself.'

The preliminary data presented in this paper clearly indicates that the delivery of enabling programs online provides access and opportunity for many disadvantaged students who are interested in pursuing higher 
education. In 2012 over 1,300 students completed an enabling program at the University of Newcastle. Based on their academic performance, over $97 \%(1,261)$ of these students received an offer to an undergraduate program. Once in undergraduate degrees, internal data shows that enabling students perform similarly to 'traditional' commencing students. A review of performance data at undergraduate level shows that the progression rate of first year domestic students who entered into the University directly is $84 \%$, compared to $80 \%$ among students who entered via an enabling program. By comparison, the first year progression rate for domestic students across Australia in undergraduate programs in 2012 was 83\% (Department of Education, 2012). Table 1 outlines the 2012 benchmarked data on progression with national, institutional, and students who completed enabling programs.

Table 1: Benchmarking of Progression rate

\begin{tabular}{|l|l|}
\hline Progression rates & $\mathbf{2 0 1 2}$ \\
\hline $\begin{array}{l}\text { National commencing domestic student progression in } \\
\text { undergraduate study }\end{array}$ & $83 \%$ \\
\hline $\begin{array}{l}\text { University commencing domestic student progression in } \\
\text { undergraduate study }\end{array}$ & $84 \%$ \\
\hline $\begin{array}{l}\text { Progression of commencing domestic students completing } \\
\text { enabling program in undergraduate study }\end{array}$ & $80 \%$ \\
\hline
\end{tabular}

Due to the barriers faced by enabling students, and the fact that these barriers do not disappear with transition into undergraduate study, it can be argued that $80 \%$ progression in the first year of undergraduate education is at least in part a reflection of the level of preparation attained by these students in their enabling year. Similarly the attrition of first year domestic undergraduate students who enter the University directly is $18 \%$, compared to $23 \%$ for enabling completers. Once again, this is similar to the national attrition rate of $19 \%$ among first year domestic students undertaking undergraduate courses (Department of Education, 2012).

\section{Conclusion}

Many countries are aiming to increase the participation in higher education of students from disadvantaged backgrounds. The University of Newcastle has had a mechanism for achieving this for the past forty years. Since 1973, the Open Foundation enabling program has made access to higher education a possibility for thousands of non-traditional students. Amidst a world-wide increase in the demand for online courses, this program is now taught online as well as on-campus. Between 2008 and 2013, a diverse range of students have sought the flexibility and accessibility of undertaking their enabling program online. Enrolment statistics show that more students in numerous categories of disadvantage are choosing online over on-campus study, and that the proportion of students in these categories has exceeded Australian national targets. Just over $58 \%$ of the students who enrol in the online program are over the age of 25 and such people typically have more 
complex lives than school leavers. Therefore, online study is seen as an option which may allow successful juggling of their various responsibilities. Moreover, almost three-quarters of enrolling students are women, and they report that the greater flexibility that the online program enables them to combine study with their employment and caring responsibilities. Many of these students are also from low socio-economic, regional or remote areas. Although only small numbers of students are from Indigenous backgrounds, the percentage of these students in each yearly intake is still more than three times the participation rate of Indigenous students across the Australian higher education sector. Student comments reinforce that the flexibility of online study is important for many women returning to education while balancing carer commitments, and indicate that the online program provides an opportunity to prove one's capabilities and build confidence within a safe and supportive academic environment.

It is clear that students enrolling in Open Foundation Online appreciate being able to study at times and places convenient to them as they continue to manage their complex lives. This gives them confidence not only to succeed at an enabling level, but also promotes confidence for undergraduate studies. This preliminary finding on the Open Foundation Online program demonstrates that delivering enabling courses and programs online is assisting disadvantaged students to circumvent some of the impediments that they have faced in their educational journeys. While enabling programs have provided access and opportunity for many disadvantaged students - the ongoing sustainability of the program may be at risk as the current government in Australia plans to expand the provision of sub-degree programs with funding provided to university and nonuniversity providers (Kemp and Norton, 2014). The new policy and funding may see the rise of private providers offering associate degrees and diplomas with articulation into undergraduate study. Future research will examine this phenomenon more deeply by examining the social and economic outcomes of widening student participation through online enabling education, and the impact on individuals, families and the community.

\section{References}

Ashby, J., Sadera, W. A., and Mcnary, S. W. (2011). 'Comparing student success between developmental math courses offered online, blended, and face-toface', Journal of Interactive Online Learning, 10, 3: 128-140.

Behrendt, L., Larkin, S., Griew, R. and Kelly, P. (2012) 'Review of Higher Education Access and Outcomes for Aboriginal and Torres Strait Islander People: Final Report', Commonwealth of Australia, at http://www.innovation.gov.au/HigherEducation/IndigenousHigherEducation/ ReviewOfIndigenousHigherEducation/FinalReport/IHERFinalReport.pdf (accessed: 13 November 2013)

Beyer, S. (1995). Maternal employment and children's academic achievement: Parenting styles as a mediating variable. Developmental Review, 15, 212-253. 
Birrell, B., Calderon, A., Dobson, I. and Smith, T. (2000) 'Equity in access to higher education revisited’, People and Place, 8, 1: 50-60.

Bossu, C., Bull, D. and Brown, M. (2012) 'Opening up Down Under: the role of open educational resources in promoting social inclusion in Australia', Distance Education, 33, 2: 151-164.

Bowers-Brown, T. (2006). Widening participation in higher education amongst students from disadvantaged socio-economic groups, Tertiary Education and Management, 12 (1) 59-74

Bowl, M. (2001) 'Experiencing the barriers: non-traditional students entering higher education', Research Papers in Education, 16, 2: 141-160.

Bradley, D., Noonan, P., Nugent, H. and Scales, B. (2008) 'Review of Australian Higher Education: Final Report', Commonwealth of Australia, at: http://www.innovation.gov.au/highereducation/ResourcesAndPublications/Re viewOfAustralianHigherEducation/Pages/ReviewOfAustralianHigherEducati onReport.aspx (accessed: 13 November 2013)

Brown, M., Keppell, M., Hughes, H., Hard, N., Shillington, S., and Smith, L. (2012) 'Superficial social inclusion? Reflections from first-time distance learners. A Practice Report', The International Journal of the First Year in Higher Education, 3, 2: 73-80.

Cantwell, R., Archer, J. and Bourke, S. (2001) 'A comparison of the academic experiences and achievement of University students entering by traditional and non-traditional means', Assessment \& Evaluation in Higher Education, 26, 3: 221-234.

Cantwell, R.H. and Mulhearn, W. (1997) The adjustment behaviours of matureaged women returning to formal study, paper presented to the Australian Association for Research in Education Conference, Brisbane.

Chen, D. (2003) 'Uncovering the provisos behind flexible learning', Educational Technology \& Society, 6, 2: 25-30.

Clayton, P.M. (1999) Access to vocational guidance for people at risk of social exclusion, Glasgow: University of Glasgow.

Collins, J. and Penglase, B. (1991) 'Offering a second chance - who accepts? Characteristics of entrants to the University of Newcastle Open Foundation Course', Australian Journal of Adult and Community Education, 31, 3: 189195.

Crossan, B., Field, J., Gallacher, J. and Merrill, B. (2003) ‘Understanding participation in learning for non-traditional adult learners: learning careers and the construction of learning identities', British Journal of Sociology of Education, 24, 1: 55-67.

Cullity, M. (2006) 'Challenges in understanding and assisting mature-age students who participate in alternative entry programs', Australian Journal of Adult Learning, 46, 2: 175-201.

Dawson, P., Charman, K. and Kilpatrick, S. (2013) 'The new higher education reality: what is an appropriate model to address the widening participation agenda?' Higher Education Research \& Development, 32, 50: 706-721. 
Debenham, M. (2001) Computer mediated communication and disability support: addressing barriers to study for undergraduate distance learners with longterm health problems, unpublished $\mathrm{PhD}$ thesis. Milton Keynes: Open University.

Dell, C. A., Low, C. and Wilker, J. F. (2010) 'Comparing student achievement in online and face-to-face class formats', MERLOT Journal of Online Learning and Teaching, 6, 1: 30-42.

Department for Business Innovation and Skills (2009) Higher Ambitions: The Future of Universities in a Knowledge Economy, at http://www.bis.gov.uk/policies/higher-ambitions (accessed: 13 November 2013)

Department of Education (2012) Selected Higher Education Statistics - 2012 Student Data, at: http://education.gov.au/selected-higher-education-statistics2012-student-data (accessed: 12 February 2014)

Department of Industry, Innovation, Climate Change, Science, Research and Tertiary Education (2013) Student 2012 Full Year: Selected Higher Education Statistics, at: http://www.innovation.gov.au/highereducation/HigherEducationStatistics/Stat isticsPublications/Pages/Students12FullYear.aspx (accessed: 13 November 2013)

Department of Education (1997) A Programme for the Transformation of Higher Education, at http://www.che.ac.za/sites/default/files/publications/White_Paper3.pdf (accessed: 13 November 2013)

Department of Education, Employment and Workplace Relations (2009)

Transforming Australia's Higher Education System, at http://www.innovation.gov.au/highereducation/Documents/TransformingAus HigherED.pdf (accessed: 13 November 2013)

Department of Employment, Education and Training and National Board of Employment, Education and Training (1990), A Fair Chance for All: National and Institutional Planning for Equity in Higher Education, A Discussion Paper, Commonwealth of Australia, at http://hdl.voced.edu.au/10707/152620 (accessed: 13 November 2013)

Diaz, L.A. and Entonado, F.B. (2009) 'Are the Functions of Teachers in e-Learning and Face-to-Face Learning Environments Really Different?', Educational Technology \& Society, 12, 4: 331-43.

Garrett, R., and Jokivirta, L. (2004) 'Online learning in Commonwealth Universities: Selected data from the 2004 Observatory survey, Part 1'. Observatory on Borderless Higher Education, at: http://www.obhe.ac.uk/documents/view_details?id=51 (accessed: 13 November 2013)

Gorard, S. and Selwyn, N. (1999) 'Switching on the learning society? questioning the role of technology in widening participation in lifelong learning', Journal of Educational Policy, 14, 5: 523-534. 
Heaton-Shrestha, C., May, S. and Burke, L. (2009) 'Student retention in higher education: what role for virtual learning environments', Journal of Further and Higher Education, 33, 1: 83-92.

James, R., Baldwin, G., Coates, H., Krause, K-L. and McInnis, C. (2004). Analysis of equity groups in higher education: 1991-2002, Centre for the Study of Higher Education, University of Melbourne, Victoria, at http://cshe.unimelb.edu.au/research/equity/docs/equity_report_final.pdf (accessed: 13 November 2013)

Kaler, B. C. (2012) 'A model of successful adaptation to online learning for college-bound Native American high school students', Multicultural Education \& Technology Journal, 6, 2: 60-76.

Kavanagh, K., Challinor, M., Clark, H., Hodges, B., McCall, D., Mahyuddin, J., et al. (2011), Challenging the past: [Re]constructing a distance enabling model to enhance student participation, paper presented at the 1st International Australasian Conference on Enabling Access to Higher Education, Adelaide.

Kaziboni, T. (2000) 'Picking up threads - women pursuing further studies at the University of Zimbawe', Studies in the Education of Adults, 32, 2: 229-241.

Kemmer, D. (2011/12) 'Blended learning and the development of student responsibility for learning: a case study of a 'widening access' university', Widening Participation and Lifelong Learning, 13, 3: 60-73.

Kemp, D. and Norton, A. (2014). Review of Demand-Driven Funding System, at: http://docs.education.gov.au/system/files/doc/other/review_of the_demand_d riven_funding_system_report_for_the_website.pdf (accessed: 17 July 2014).

Knightley, M, W. (2007) 'Adult learners online: students' experiences of learning online', Australian Journal of Adult Learning, 47, 2: 264-288.

Krause, K., Hartley, R., James, R. and McInnis, C. (2005). The First Year Experience in Australian Universities: Findings from a Decade of National Studies, Centre for the Study of Higher Education, University of Melbourne, at:

http://www.griffith.edu.au/ data/assets/pdf file/0006/37491/FYEReport05.p df (accessed: 13 November 2013)

Kwapong, O. (2008) 'A Case for using Open and Distance Learning (ODL) to Widen Access to Tertiary Education for Women', International Journal of Instructional Technology and Distance Learning, 5, 5: 47-57.

Ladyshewsky, R. K. (2004) 'E-learning compared with face to face: differences in the academic achievement of postgraduate business students', Australasian Journal of Educational Technology, 20, 3: 316-336, at: http://ascilite.org.au/ajet/ (accessed: 22 April 2014)

Lane, A. (2012) 'A review of the role of national policy and institutional mission in European distance teaching universities with respect to widening participation in higher education study through open educational resources', Distance Education, 33, 2: 135-150.

Lax, S. (2001) Information, education and inequality: is new technology the solution? in Lax, S. (ed.) Access denied in the information age, Basingstoke: Palgrave. 
Long, G., Marchetti, C. and Fasse, R. (2011) 'The importance of interaction for academic success in online courses with hearing, deaf, and hard-of-hearing students', The International Review of Research in Open and Distance Learning, 12, 6, at: http://www.irrodl.org/ (accessed 24 April 2014)

Looi, C. and Lim, W. (2006) Integration of ICT for sustainability: perspectives for educational research, paper presented at the American Educational Research Association Annual Meeting, San Francisco, USA.

Li, F., Zhou, M. and Fan, B. (2013) 'Can distance education increase educational equality? Evidence from the expansion of Chinese higher education', Studies in Higher Education, in press.

Martin, S. and Williamson, W. (2002) 'Included in exclusion: learning, civil society and widening participation', Journal of Access and Credit Studies, Autumn: 51-62.

Matas, C.P. and Allan, C. (2004) 'Using learning portfolios to develop generic skills with on-line adult students', Australian Journal of Adult Learning, 44, 1: 6-26.

McDonald, J. and Renshle, S. (2000) 'Engagement in web-based education: designing for models of student learning', Indian Journal of Open Learning, 9, 3: 287-297.

McFadden, M.G. (1995) 'Second chance education: settling old scores', Journal of Access Studies, 10: 49-50.

Mckendry, S. (2012/13) 'Investigating the possibilities for online delivery of a successful campus based pre-entry programme’, Widening Participation and Lifelong Learning, 14, 3: 216-234.

McPhee, I. and Söderström, T. (2012) 'Distance, online and campus higher education: reflections on learning outcomes', Campus-Wide Information Systems, 29, 3: 144-155.

Ministry of Education (2010) Tertiary Education Strategy 2010-2015, at http://www.minedu.govt.nz/NZEducation/EducationPolicies/TertiaryEducatio n/PolicyAndStrategy/TertiaryEducationStrategy.aspx (accessed: 13 November 2013)

Navarro, P. and Shoemaker, J. (2000) 'Performance and perceptions of distance learners in cyberspace', American Journal of Distance Education, 14 2: 1535.

Organisation for Economic Co-operation and Development. (2005). E-learning in tertiary education: where do we stand? Paris: OECD/CERI

Organisation for Economic Co-operation and Development. (2006). Higher education: Quality, equity and efficiency (Background Report), at http://www.oecd.org/dataoecd/30/7/36960580.pdf (accessed: 13 November 2013)

Packham, G., Jones, P., Miller, C. and Thomas, B. (2004) 'E-learning and retention: key factors influencing student withdrawal', Education and Training, 47, 6/7: 335-342.

Phillimore, J. and Koshy, P. (2010) 'Implications of the Proposed Low SES Participation Target for Australian University Enrolments: Final Report', 
Australian Technology Network of Universities, at http://www.atn.edu.au/Documents/2011/2010/John\%20Curtin\%20Institute\%2 0for\%20public\%20policy.pdf (accessed: 13 November 2013)

Ramsay, E. (2004) 'Blurring the boundaries and re-thinking the categories: Implications of enabling education for the mainstream post-compulsory sector', Australian Journal of Adult Learning, 44, 3: 273-305.

Richardson, J. T. E. (2012) 'Face-to-face versus online tuition: Preference, performance and pass rates in white and ethnic minority students', British Journal of Educational Technology, 43, 1: 17-27.

Schiffman, S., Vignare, K. and Geith, C. (2007) 'Why do higher education institutions pursue online education?', Journal of Asynchronous Learning Networks, 11, 2: 61-71.

Segrave, R. (2004) 'Communication technologies and knowledge building in agriculture’, Australian Journal of Adult Learning, 44,1: 27-43.

Shah, M., Lewis, I. and Fitzgerald, R. (2011) 'The Renewal of Quality Assurance in Australian Higher Education: The Challenge of Balancing Academic Rigor, Equity and Quality Outcomes', Quality in Higher Education, 17, 3: 265-278.

Simpson, O. (2005). E-learning and the future of distance education in the markets of the $21^{\text {st }}$ century, in Carr-Chelman, A.A. (ed.), Global perspectives on elearning: rhetoric and reality, London: Sage Publications Inc.

Sturgis, I. (2012) 'More colleges are exploring Web-based teaching to better serve diverse student populations', The Online Frontier, 15 March, at http://www.readperiodicals.com/201203/2630184761.html (accessed: 15 November 2013)

The Age (2011) 'Quality must not be sacrificed to quantity’, 2 March, pp. 5.

The Chronicle (2010) 'Obama: education is the economic issue of our time', August 11, pp. 46.

Tight, M. (2012) 'Widening Participation: A Post- War Scorecard', British Journal of Educational Studies, 60, 3: 211-226.

Tones, M. J., Fraser, J., Elder, R. L. and White, K. M. (2009) 'Supporting matureaged students from a low socioeconomic background’, Higher Education, 58, 4: 505-529.

Trounson, A. and Hare, J. (2011) 'Minister Chris Evans warns universities ahead of uncapping', The Australian, 2 March.

Western, J., McMillan, J. and Durrington, D. (1998). Differential Access to Higher Education: The Measurement of Socioeconomic Status, Rurality and Isolation, Department of Education, Training and Youth Affairs, at http://vital.new.voced.edu.au/vital/access/services/Download/ngv:7000/SOU RCE2 (accessed: 13 November 2013)

Whiteford, G., Shah, M. and Nair, S. (2013) 'Equity and excellence are not mutually exclusive: a discussion of academic standards in an era of widening participation’, Quality Assurance in Education, 21, 3: 299-310. 
Whittington, K., Cook, J., Barratt, C. and Jenkins, J. (2004) 'Can the Internet widen participation in reproductive medicine education for professionals?', Human Reproduction, 19, 8: 1800-1805. 
Copyright of Widening Participation \& Lifelong Learning is the property of Open University, Centre for Widening Participation and its content may not be copied or emailed to multiple sites or posted to a listserv without the copyright holder's express written permission.

However, users may print, download, or email articles for individual use. 